\title{
Properties of Modified Phenol-Formaldehyde Adhesive for Plywood Panels Manufactured from High Moisture Content Veneer
}

\section{Svojstva modificiranoga fenol-formaldehidnog ljepila za furnirske ploče proizvedene od furnira s visokim sadržajem vode}

\author{
Original scientific paper • Izvorni znanstveni rad \\ Received-prispjelo: 16. 9. 2013. \\ Accepted-prihvaćeno: 13. 10. 2014. \\ UDK: $630 * 832.282 .6 ; 630 * 824.325$ \\ doi:10.5552/drind.2014.1350
}

\begin{abstract}
This paper presents the results of laboratory investigations of bonding high moisture content (15\%) birch veneers (Betula pubescens Ehrh.) with the use of modified phenol-formaldehyde (PF) resin. Wheat starch, rye flour, resorcinol and phenol-resorcinol-formaldehyde resin were chosen as modifying agents. Dynamic viscosity, hydrogen ions concentration, solid content, curing time, pot life of developed adhesive compositions and shear strength of plywood samples were evaluated. ANOVA analysis has shown that type, mixture and content of modifying agents affect significantly the mechanical performance of plywood panels. The obtained results of shear strength values were above the standard requirements $\left(1 \mathrm{~N} / \mathrm{mm}^{2}\right)$, and the properties of samples met the European standard EN 314-2 for gluing quality of class 3 and such plywood panels can be used in exterior conditions.
\end{abstract}

Key words: gluing, veneer, high moisture content, plywood, phenol-formaldehyde resin, modifying agents

SAŽETAK • U radu su prikazani rezultati laboratorijskih istraživanja furnirskih ploča proizvedenih od furnira od drva breze (Betula pubescens Ehrh.) s visokim sadržajem vode (15\%) i uz primjenu modificiranoga fenol-formaldehidnog (PF) ljepila. Pšenični škrob, raženo brašno, rezorcinol i fenol-rezorcinol-formaldehidna smola izabrani su kao sredstva za modificiranje. Analizirane su dinamička viskoznost, koncentracija vodikovih iona, sadržaj krute tvari, vrijeme otvrdnjavanja, otvoreno vrijeme smjese za lijepljenje i smicajna čvrstoća uzoraka furnirskih ploča. ANOVA analiza pokazala je da vrsta, smjesa i težinski udjel sredstava za modifikaciju ljepila značajno utječu na mehanička svojstva furnirskih ploča. Dobivene vrijednosti čvrstoće smicanja iznad su standardnih zahtjeva (1 N/

\footnotetext{
${ }^{1}$ Authors are professor and assistant at Department of Wood-Based Composites, National University of Forestry \& Wood Technology of Ukraine, Lviv, Ukraine. ${ }^{2}$ Author is professor at Department of Furniture and Wood Products, Technical University in Zvolen, Zvolen, Slovakia.

' Autori su profesor i asistentica Odjela za drvne kompozite Nacionalnog sveučilišta šumarstva i drvne tehnologije Ukrajine, Lviv, Ukrajina.

${ }^{2}$ Autor je profesor Odjela za namještaj i drvne proizvode Tehničkog sveučilišta u Zvolenu, Zvolen, Slovačka.
} 
$\mathrm{mm}^{2}$ ), a svojstva uzoraka furnirskih ploča zadovoljavaju europsku normu EN 314-2 za kvalitetu lijepljenja klase 3 koja se odnosi na furnirske ploče koje se mogu rabiti u vanjskim uvjetima.

Ključne riječi: lijepljenje, furnir, visok sadržaj vode, furnirska ploča, fenol-formaldehidno ljepilo, sredstva za modificiranje

\section{INTRODUCTION} 1. UVOD

The process of gluing of veneer-based products, as plywood or laminated veneer lumber, is significantly affected by the moisture content in wood combined with water in an adhesive. This moisture directly influences the curing process and properties of the used adhesive, economic costs (consumption of glue, pressing time and costs for veneer drying) as well as physical and mechanical properties of veneer-based products. Nowadays in Ukraine, construction plywood is generally produced with adhesives based on phenol-formaldehyde resins and veneers that should be dried to $8 \%$ moisture content. For such moisture content the conventional thermo-reactive adhesives provide highquality bonding of plywood with physical and mechanical performances that meet European standard requirements. Gluing of veneers with lower moisture content $(W<8 \pm 2 \%$ ) involves the following disadvantages: high consumption of energy for drying, brittleness of veneers, rapid adhesive viscosity increase by diffusion of water into the cellular structure, worsened wetting and insufficient transfer of adhesive to another surface. Gluing of veneer with higher initial moisture content ( $W>8 \pm 2 \%$ ) has the following disadvantages: increasing adhesive penetration by the flow inside the vessel network through the veneer thickness, high vapour pressure causing steam blisters or blows, decreasing the viscosity of the applied adhesive layer, and loss of wood mass as well as thickness due to compression. There is a risk of forming of discontinuous glue layer on veneer surface, retardation of glue curing or creation of insufficient joints. Furthermore, the process of plywood manufacture is characterized by significant energy costs for veneer drying (almost $60 \%$ ) and hot pressing (15\%), which significantly affects the cost of production. Therefore, using veneers with higher moisture would result in substantial savings of energy.

Recent developments and trends in the field of eco-efficient bonding technologies contribute to both ecological and economical aspects. Several new trends are in application of vegetable carbohydrates or proteins, namely as modifiers of existing adhesives. Addition of polysaccharides or soy proteins to traditional synthetic wood adhesives after partial hydrolysis and modifications has been reported (Pizzi, 2006). Some articles (Besinova et al., 1997; Elbez, 1997) were oriented on benefits of gluing high moisture veneers. More studies were performed on possibilities of bonding high moisture veneers using phenol-formaldehyde resin filled by hydrolysed soy protein, starch and tannin (Vijayendran et al., 2000). Other researchers prepared high solid PF adhesive mixtures with increased reactivity by grafting resorcinol (Clark et al., 1988) or they modified PF resin (Steiner et al., 1993) that consisted of an alkaline insoluble but swellable dispersed PF phase, an alkaline soluble continuous phase and propylene carbonate additive. Some systems of filling with pecan shell flour and two furfural-process residues were tested (Sellers et al., 1990). One of them involves mixing a high molecular weight resin with alkylene carbonates or phenol-resorcinol-formaldehyde resins (Clarke et al., 1990).

The wood porosity is one of the main physical indexes in wood science. Bonding of wood elements with higher moisture content is a difficult process; the details of the penetration of the hardening adhesives into the porous wood skeleton are rather complicated. It is strongly influenced by factors as wood species, grain orientation and surface roughness, adhesive factors as type of adhesive, solid content and viscosity, and process factors as applied pressure and temperature, which have the most significant influence on the bonding performance (Kamke and Lee, 2007; Varivodina et al., 2010). An analytical model to predict the penetration of adhesives into hardwood was proposed (Mendoza et al., 2012). The model considers a dimensional capillary fluid transport of a hardening adhesive through a single, straight vessel with diffusion of solvent through the walls of the vessel. Adhesive penetration follows the path of lowest resistance into the porous structure, either by gross penetration or by cell wall penetration. The bond line morphologies and the adhesive penetration into the wood structure were evaluated (Haas, 2012) after determining the hardening characteristics of adhesives.

The viscoelastic characteristics of wood play an important role in compression and densification. At high temperature and high moisture content, wood exhibits plastic behaviour that can be characterized as inconvenient. Temperature and conditions of pressing process affect the change of relative density and creep deformation, as well as properties of the resulting pressed plywood material. The dependence of inelastic behaviour of the gross wood on the elastic properties of the cell wall allows the time, temperature, and moisture dependence to be modelled with classical linear viscoelastic theory of amorphous polymers. Time-temperature-moisture relationship was shown (Wolcott et al., 1994) to be applicable to stress relaxation data collected for temperatures between 39 and $99{ }^{\circ} \mathrm{C}$ and moisture contents between 3 and $16 \%$.

The bond strength of thermosetting PF adhesives is developing during the hardening process carried out in a hot-press at stated pressure, temperature and for a defined period of time. Pressure parameters are influenced by several factors as thickness of the composite, thermal conductivity, or moisture content of the material. Pressure must be kept till strength of cured adhe- 
sive is higher than forces of internal vapour. Research has shown that the degree of cure is dependent on the pressing time and on the composition of the PF adhesive (Jost and Sernek, 2009). The temperature inside the bond line is firstly rapidly increasing slightly above $100{ }^{\circ} \mathrm{C}$. The temperature stays around this level for the time of energy consumption for the evaporation of water from the veneer and adhesive. After that period the temperature is increasing up to the set pressing temperature. Significant mechanical strength in the adhesive bond was established in the last stage of the curing, when crosslinking of the PF adhesive occurred.

However, all of these above mentioned measures require the use of expensive adhesives, replacement of existing equipment, additional processing steps that can lead to significant investment and thus increase the cost of end products. These methods have not thereby found their use in the manufacture of plywood, so the question of bonding veneer of high moisture content is still important.

Therefore, the purpose of this study was to develop the adhesive compositions that allow gluing veneers with higher moisture content (up to $15 \%$ ) to provide the desired strength properties of plywood and veneer-based materials.

\section{MATERIALS AND METHODS}

\section{MATERIJALI I METODE}

Rotary cut veneer sheets of birch wood (Betula pubescens Ehrh.) with dimensions of $300 \times 300 \mathrm{~mm}$ and thickness of $1.5 \mathrm{~mm}$ without visible defects were prepared for the experiments. Commercial PF resin generally used for plywood with the following parameters: solid content $48.3 \%$, dynamic viscosity 790 $\mathrm{mPa} \cdot \mathrm{s}$, was used in this research. Wheat starch (WS), rye flour (RF), technical resorcinol (R) and phenol-resorcinol-formaldehyde (PRF) resin were chosen as modifying agents.

High moisture content of veneer slows the curing of PF glue. Resorcinol and PRF resin are suggested to be added into $P F$ resin to accelerate the adhesive curing process for improving its water resistance and increasing the adhesion of glue to the veneer with high moisture content. Resorcinol has a coherent orientation of $-\mathrm{OH}$ groups and its addition, or addition of PRF resin into PF resin will allow creating additional bonds with wood (phenyl-propane units). Adding of wheat starch and rye flour into PF resin allows taking excessive moisture from the glue, because they both absorb and swell in water very well. In addition, they prevent the penetration of glue into wood and through thin layers of veneer on the front surface of the plywood.

High moisture content level of $15 \%$ was achieved by conditioning of dry veneer sheets inside a chamber at constant temperature over sulphuric acid solution with concentration of $30 \%$, till achieving the desired level of moisture content. The moisture content was controlled using electronic moisture-meter and exactly stated by weight method.

The adhesives compositions (Table 1) were proposed and the effect of modifying agents on their prop- erties was investigated. The amount of added modifying agents was of 1,3 , and 5 weight parts per 100 weight parts of phenol-formaldehyde resin. Dynamic viscosity, hydrogen ions concentration $(\mathrm{pH})$, solid content, curing time and pot life of adhesive compositions as well as shear strength of plywood panels were evaluated.

Solid content of prepared adhesive mixtures was determined by weight method. Curing time of adhesive mixtures was determined at the temperature of $150{ }^{\circ} \mathrm{C}$. Dynamic viscosity was measured by the rotational viscometer at $20^{\circ} \mathrm{C}$ and hydrogen ion concentration of the prepared adhesives was determined on $\mathrm{pH}$-meter. Curing time of adhesive mixtures was determined on a steel disk at the temperature of $150{ }^{\circ} \mathrm{C}$ and pot life as the increase of the dynamic viscosity.

Table 1 Adhesive compositions

Tablica 1. Sastavi smjese za lijepljenje

\begin{tabular}{|c|c|c|c|c|c|c|c|}
\hline \multirow{2}{*}{$\begin{array}{l}\text { Number of } \\
\text { adhesive } \\
\text { composition } \\
\text { Broj sastava } \\
\quad \text { ljepila }\end{array}$} & \multicolumn{7}{|c|}{$\begin{array}{l}\text { Adhesive modifiers, weight parts } \\
\text { Sredstvo za modifikaciju, težinski udio }\end{array}$} \\
\hline & $\mathrm{PF}$ & $\begin{array}{c}30 \\
\% \\
\mathrm{R}^{*}\end{array}$ & $\begin{array}{l}40 \\
\% \\
\mathrm{R}^{*}\end{array}$ & $\begin{array}{l}50 \\
\% \\
\mathrm{R}^{*}\end{array}$ & PRF & WS & $\mathrm{RF}$ \\
\hline 0 & 100 & - & - & - & - & - & - \\
\hline 1 & 100 & 1 & - & - & - & - & - \\
\hline 2 & 100 & 3 & - & - & - & - & - \\
\hline 3 & 100 & 5 & - & - & - & - & - \\
\hline 4 & 100 & - & 1 & - & - & - & - \\
\hline 5 & 100 & - & 3 & - & - & - & - \\
\hline 6 & 100 & - & 5 & - & - & - & - \\
\hline 7 & 100 & - & - & 1 & - & - & - \\
\hline 8 & 100 & - & - & 3 & - & - & - \\
\hline 9 & 100 & - & - & 5 & - & - & - \\
\hline 10 & 100 & - & - & - & 1 & - & - \\
\hline 11 & 100 & - & - & - & 3 & - & - \\
\hline 12 & 100 & - & - & - & 5 & - & - \\
\hline 13 & 100 & - & - & - & - & 1 & - \\
\hline 14 & 100 & - & - & - & - & 3 & - \\
\hline 15 & 100 & - & - & - & - & 5 & - \\
\hline 16 & 100 & - & - & - & - & - & 1 \\
\hline 17 & 100 & - & - & - & - & - & 3 \\
\hline 18 & 100 & - & - & - & - & - & 5 \\
\hline 19 & 100 & 1 & - & - & - & 3 & - \\
\hline 20 & 100 & - & 1 & - & - & 3 & - \\
\hline 21 & 100 & - & - & 1 & - & 3 & - \\
\hline 22 & 100 & - & - & - & 1 & 3 & - \\
\hline 23 & 100 & 3 & - & - & - & 3 & - \\
\hline 24 & 100 & - & 3 & - & - & 3 & - \\
\hline 25 & 100 & - & - & 3 & - & 3 & - \\
\hline 26 & 100 & - & - & - & 3 & 3 & - \\
\hline 27 & 100 & 1 & - & - & - & - & 3 \\
\hline 28 & 100 & - & 1 & - & - & - & 3 \\
\hline 29 & 100 & - & - & 1 & - & - & 3 \\
\hline 30 & 100 & - & - & - & 1 & - & 3 \\
\hline 31 & 100 & 3 & - & - & - & - & 3 \\
\hline 32 & 100 & - & 3 & - & - & - & 3 \\
\hline 33 & 100 & - & - & 3 & - & - & 3 \\
\hline 34 & 100 & - & - & - & 3 & - & 3 \\
\hline
\end{tabular}

*The concentration of aqueous solutions of resorcinol was $30 \%$ (30 $\% \mathrm{R}), 40 \%(40 \% \mathrm{R})$ and $50 \%(50 \% \mathrm{R})$.

* Koncentracije vodene otopine rezorcinola bile su $30 \%$ (30\% R), $40 \%(40 \% \mathrm{R})$ i $50 \%(50 \% \mathrm{R})$. 
Three-layer plywood panels of $300 \times 300 \mathrm{~mm}$ were made in the electrically heated hydraulic laboratory press. The specific pressing pressure of $1.8 \mathrm{MPa}$ and temperature of $150{ }^{\circ} \mathrm{C}$ were used, and 6-min pressing time (during the last $30 \mathrm{~s}$ of press cycle the pressure was continually reduced to $0 \mathrm{MPa}$ ). The glue spread was $150 \mathrm{~g} / \mathrm{m}^{2}$ based on wet mass. PF adhesive mixture was applied onto one side of every uneven ply. The plies were assembled perpendicularly to each other (veneer sheets were laid up tight/loose) to form plywood of three plies. Glue was applied on the veneer surface with a hand roller spreader. Laboratory testing machine was used for the evaluation of the quality of gluing and the shear strength of plywood was determined according to EN 314-2 after pre-treatment for intended use in exterior conditions. Testing samples were immersed in boiling water for $4 \mathrm{~h}$, dried in the ventilated drying oven at $60 \pm 3{ }^{\circ} \mathrm{C}$ for $16 \mathrm{~h}$, immersed in boiling water for $4 \mathrm{~h}$, followed by cooling in water at $20 \pm 3{ }^{\circ} \mathrm{C}$ for at least $1 \mathrm{~h}$ to decrease the temperature of test pieces to $20^{\circ} \mathrm{C}$. Ten samples were used for each variant shear strength mechanical testing. During experiment, all plywood samples were conditioned before testing for two weeks at $20 \pm 2{ }^{\circ} \mathrm{C}$ and $65 \pm 5 \%$ relative humidity.

For each modifying agent, a one-way analysis of variance (ANOVA) was conducted to study the effect of type and content of modifying agents on the shear strength of plywood panels at the 0.95 confidence interval.

\section{RESULTS AND DISCUSSION}

\section{REZULTATI I RASPRAVA}

Homogeneous adhesives compositions were created when each of modifying agents was added into PF resin. Dynamic viscosity of prepared adhesive compositions increased 1.9-8.7 times, with increasing amount of resorcinol or PRF resin (Figure 1), compared with reference PF resin. Similar changes occur when adding wheat starch and rye flour (Figure 1) into PF resin. In particular, the dynamic viscosity of the adhesive increased 1.1-4.0 times, due to active adsorbing of water from the adhesive by the macromolecules of modifying extenders.

The favourable behaviour of the impact of modifying agents on curing time (Figure 2) was observed. In the case of increasing of resorcinol and PRF resin, the adhesive curing time is reduced by $20 \%$ and with the increase of wheat starch and rye flour by $50 \%$. This pattern of changes in dynamic viscosity and curing time of adhesive compositions are appropriate and can be explained by the interaction of resorcinol or PRF resin with PF resin by forming cross-links (Urbanik et al., 1997). Such cross-links increase the molecular weight of polymer, which respectively leads to the increasing of viscosity of the adhesive composition and to the fast curing (Waage et al., 1991).

Increasing amount of modifying agents leads to a decrease in pot life of adhesive mixtures, obtained values range from 1 to 5 hours (Table 2). The solid content and concentration of hydrogen ions $(\mathrm{pH})$ remain practically unchanged and are in the span from 50.1 to 57.6 $\%$ and from 11.3 to 12.0 , respectively.

An analysis of variance (ANOVA) was conducted to discern whether differences in shear strength using adhesives with various modifying agents are statistically significant. Table 3 presents ANOVA results for experimental data. This analysis found that type of modifying agents and their content in adhesive composition impacted shear strength. From the ANOVA analysis (Table 3), it is evident that the content of modifying agent is the most influencing factor on shear strength. The type of modifying agents is the next influencing factor on shear strength. In addition, the ANOVA showed that the interaction between the type

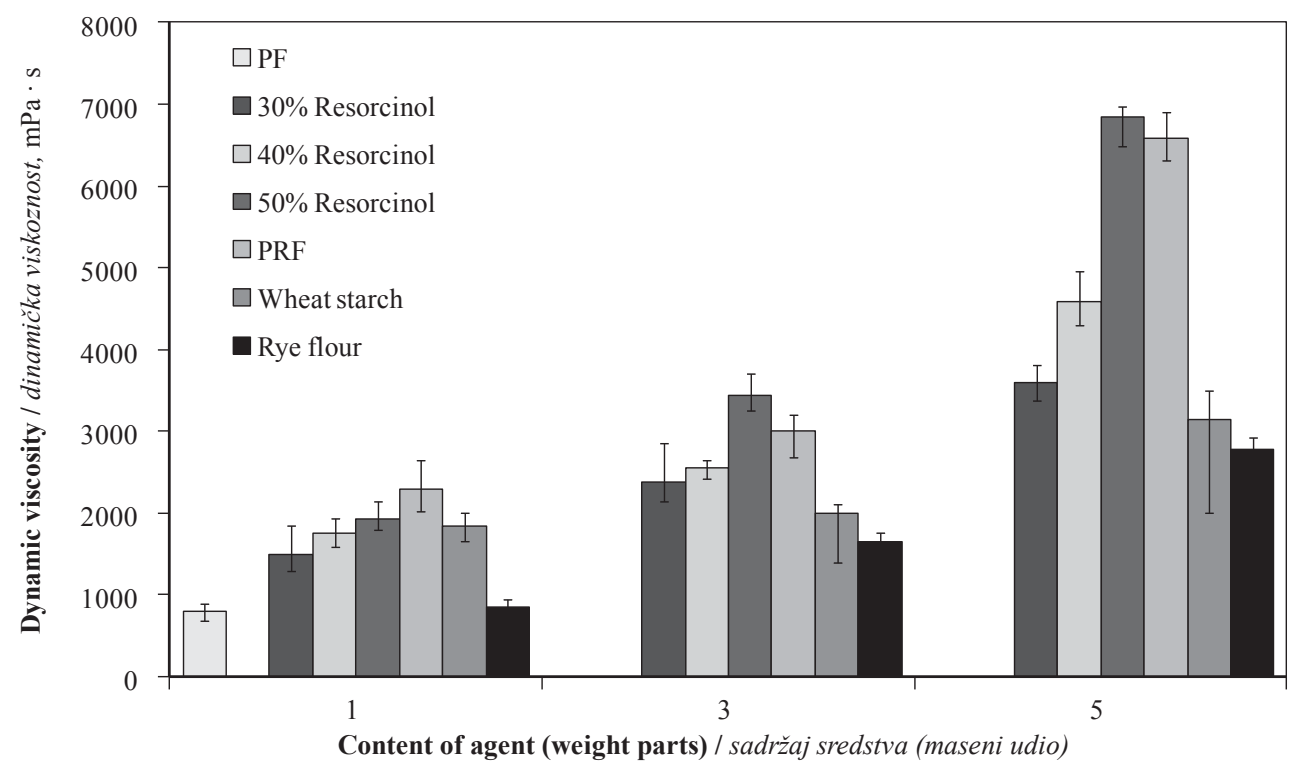

Figure 1 Dynamic viscosity of adhesive compositions

Slika 1. Dinamička viskoznost istraživanih smjesa za lijepljenje 
Table 2 Pot life of adhesive compositions

Tablica 2. Otvoreno vrijeme smjese za lijepljenje

\begin{tabular}{|c|c|c|c|c|c|c|c|}
\hline $\begin{array}{l}\text { Number of adhe- } \\
\text { sive composition } \\
\text { Broj smjese za } \\
\text { lijepljenje }\end{array}$ & $\begin{array}{l}\text { Pot life, } \\
\text { hours } \\
\text { Otvoreno } \\
\text { vrijeme, } \\
\text { sati }\end{array}$ & $\begin{array}{l}\text { Number of } \\
\text { adhesive } \\
\text { composition } \\
\text { Broj smjese za } \\
\text { lijepljenje }\end{array}$ & $\begin{array}{l}\text { Pot life, } \\
\text { hours } \\
\text { Otvoreno } \\
\text { vrijeme, } \\
\text { sati }\end{array}$ & $\begin{array}{c}\text { Number of } \\
\text { adhesive } \\
\text { composition } \\
\text { Broj smjese za } \\
\text { lijepljenje }\end{array}$ & $\begin{array}{l}\text { Pot life, } \\
\text { hours } \\
\text { Otvoreno } \\
\text { vrijeme, } \\
\text { sati }\end{array}$ & $\begin{array}{l}\text { Number of } \\
\text { adhesive } \\
\text { composition } \\
\text { Broj smjese za } \\
\text { lijepljenje }\end{array}$ & $\begin{array}{l}\text { Pot life, } \\
\text { hours } \\
\text { Otvoreno } \\
\text { vrijeme, } \\
\text { sati }\end{array}$ \\
\hline 1 & 5 & 10 & 5 & 19 & 4 & 28 & 5 \\
\hline 2 & 5 & 11 & 4 & 20 & 3 & 29 & 4 \\
\hline 3 & 4 & 12 & 1 & 21 & 3 & 30 & 4 \\
\hline 4 & 5 & 13 & 6 & 22 & 3 & 31 & 4 \\
\hline 5 & 5 & 14 & 5 & 23 & 2 & 32 & 3 \\
\hline 6 & 3 & 15 & 3 & 24 & 3 & \multirow[t]{2}{*}{33} & \multirow[t]{2}{*}{3} \\
\hline 7 & 5 & 16 & 6 & 25 & 2 & & \\
\hline 8 & 4 & 17 & 6 & 26 & 2 & \multirow[t]{2}{*}{34} & \multirow[t]{2}{*}{3} \\
\hline 9 & 3 & 18 & 6 & 27 & 5 & & \\
\hline
\end{tabular}

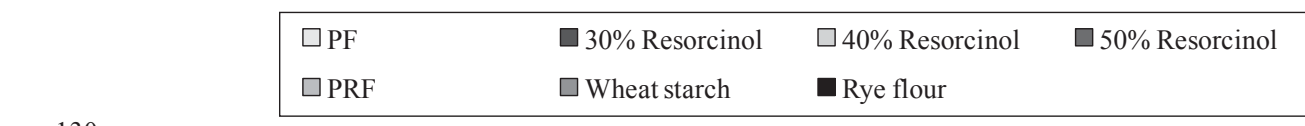

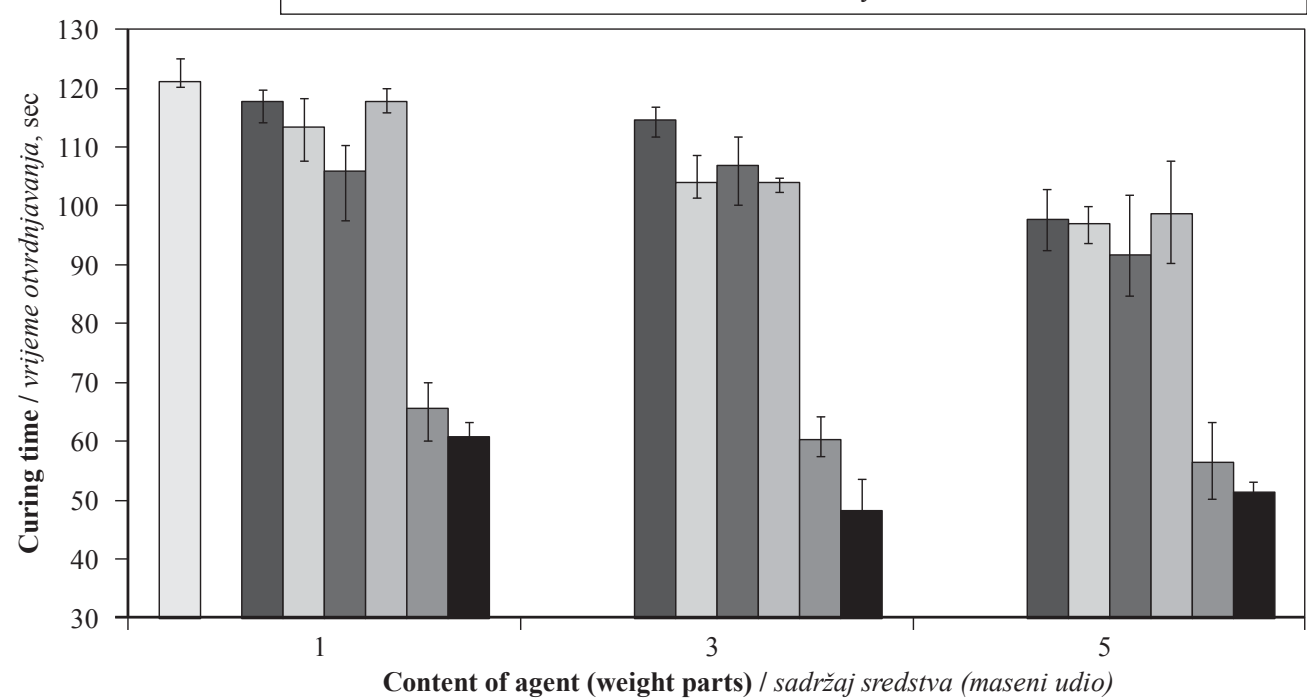

Figure 2 Curing time of adhesive compositions

Slika 2. Vrijeme otvrdnjavanja istraživanih smjesa za lijepljenje

of modifying agents and their content in adhesion composition was also significant.

The effect of modifying agents on shear strength of plywood is shown in Figure 3. In the case, if resorcinol content is increasing from 1 to 5 weight parts for all concentrations, the course of shear strength of plywood is slightly decreasing, but still is over reference sample. The reason is that resorcinol very actively reacts with PF resin, viscosity is rapidly increasing and, thus, the adhesion of glue to the wood is reduced. However, the increase in shear strength is observed when the concentration of resorcinol solutions is increasing. This can be explained by the decrease of water amount in the adhesive composition, and hence the decrease of moisture content in the glued veneer lay-up. The increase of PRF resin content in the adhesives leads to an increase in shear strength due to the formation of three-dimensional polymer network and increasing number of methylene bonds (Skeist, 1977).

Table 3 ANOVA table for shear strength of plywood panels

Tablica 3. ANOVA tablica za čvrstoću furnirskih ploča na smicanje

\begin{tabular}{|l|c|c|c|c|c|}
\hline Source / Izvor & $\boldsymbol{S S}$ & $\boldsymbol{d f}$ & $\boldsymbol{M S}$ & $\boldsymbol{F}$-ratio & $\boldsymbol{p}$-value \\
\hline Model /Model & 7.968 & 18 & 0.443 & 9.030 & 0.000 \\
\hline Modifying agents / Sredstva za modificiranje & 2.239 & 5 & 0.448 & 9.136 & 0.000 \\
\hline Content of modifying agent / Udjel sredstva za modificiranje & 1.176 & 2 & 0.588 & 11.995 & 0.000 \\
\hline Interaction / Međuodnos & 3.271 & 10 & 0.327 & 6.672 & 0.000 \\
\hline Error / Pogreška & 9.560 & 195 & 0.049 & & \\
\hline Total / Ukupno & 481.078 & 214 & & & \\
\hline
\end{tabular}

SS - Summary of squares / zbroj kvadrata, $d f$ - Degree of freedom / stupanj slobode, MS - Variance / varijanca, F-ratio - Critical value of Fischer Test / kritična vrijednost Fišerova testa, $p$ - Level of significance/ razina značajnosti 


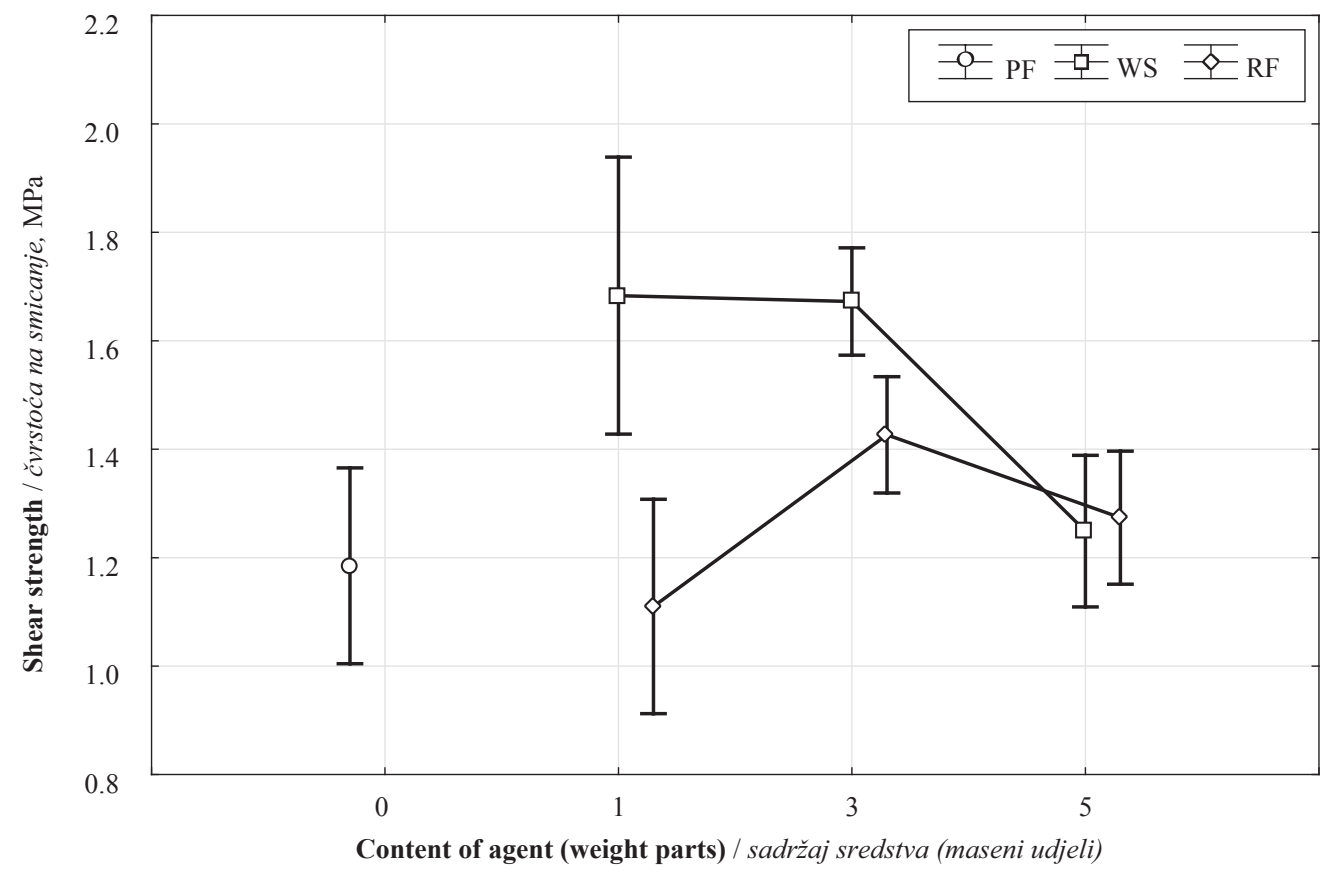

(a)

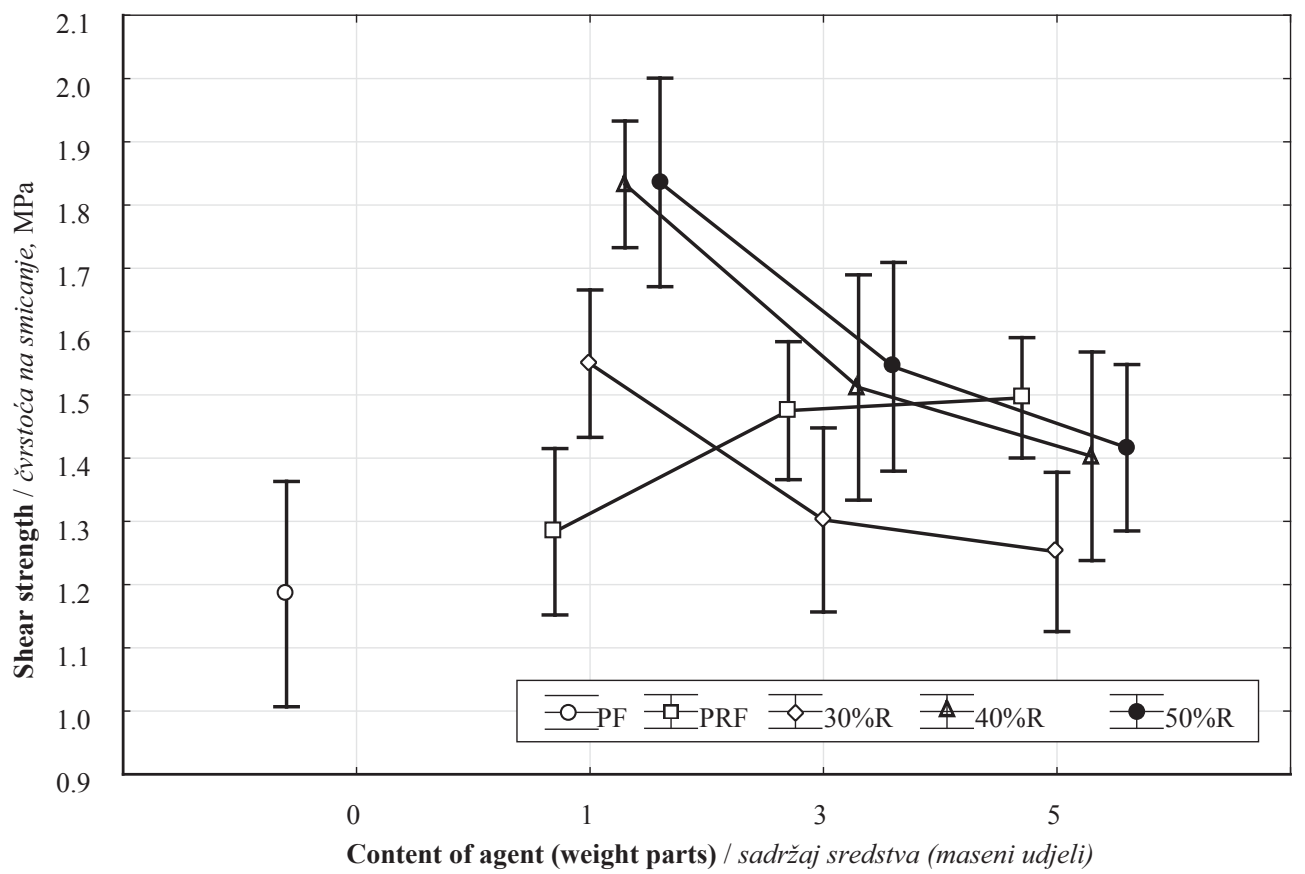

(b)

Figure 3 Shear strength of plywood panels

Slika 3. Čvrstoća furnirskih ploča na smicanje

Further to the above, in order to improve the adhesive properties and to reduce costs of resin mixture, it should be more profitable to combine the organic extenders (wheat starch and rye flour) with PRF or resorcinol modifying agents.

It was found that the dynamic viscosity of adhesive mixtures with modifying agents significantly increases up 2.8-13.3 times (Figure 4) as well as solid content 1.02-1.16 times in comparison with PF resin and, therefore, the pot life of adhesive is reduced from 5 to 2 hours. The $\mathrm{pH}$ value (11.2-11.9) is not significantly changed.
The curing time of adhesive mixtures modified by various agents was shorter ( 30.1 to $55.2 \mathrm{~s}$ ) than the curing time of adhesives only modified by one modifying agent. It was established that curing time decreases with the increase of resorcinol or PRF content in the adhesive composition (Figure 5).

Table 4 presents ANOVA results for plywood panels made using mixture of modifying agents. ANOVA tests showed that mixture of modifying agents, their content in adhesive composition and interaction between them also has statistically significant effect on the shear strength. 


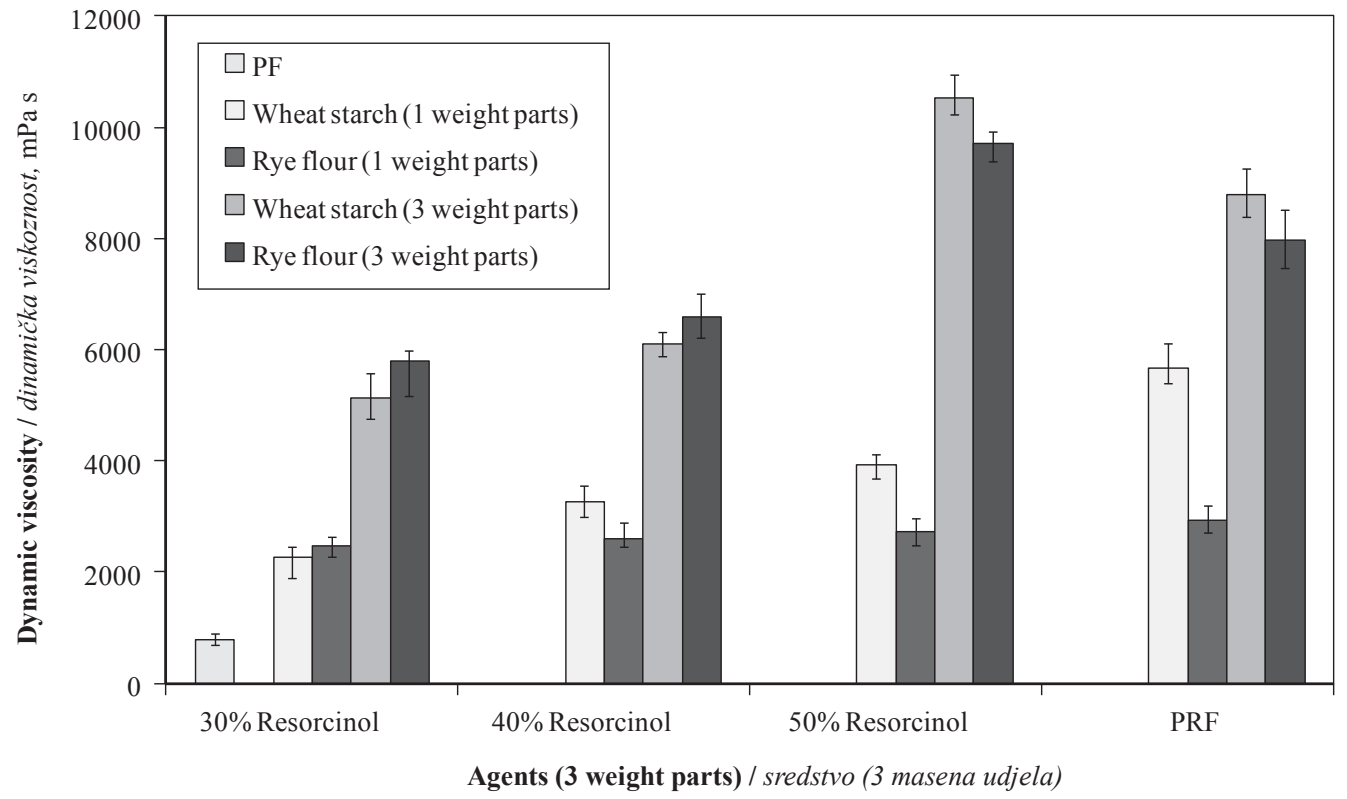

Figure 4 Dynamic viscosity of adhesive compositions with the different ratio of components Slika 4. Dinamička viskoznost smjesa za lijepljenje pri različitim omjerima komponenata

Table 4 ANOVA table for shear strength of plywood panels

Tablica 4. ANOVA tablica za čvrstoću furnirskih ploča na smicanje

\begin{tabular}{|l|c|c|c|c|c|}
\hline Source / Izvor & $\boldsymbol{S S}$ & $\boldsymbol{d f}$ & $\boldsymbol{M S}$ & $\boldsymbol{F}$-ratio & $\boldsymbol{p}$-value \\
\hline Model / Model & 6.904 & 16 & 0.432 & 12.435 & 0.000 \\
\hline Mixture of modifying agents / Smjesa sredstava za modificiranje & 5.527 & 7 & 0.790 & 22.754 & 0.000 \\
\hline Content of modifying agent / Udjel sredstva za modificiranje & .349 & 1 & 0.349 & 10.066 & 0.002 \\
\hline Interaction / Međuodnos & 1.398 & 7 & 0.200 & 5.754 & 0.000 \\
\hline Error / Pogreška & 6.316 & 182 & 0.035 & & \\
\hline Total / Ukupno & 382.352 & 199 & & & \\
\hline
\end{tabular}

$S S$ - Summary of squares / zbroj kvadrata, $d f$ - Degree of freedom / stupanj slobode, MS - Variance / varijanca, F-ratio - Critical value of Fischer Test / kritična vrijednost Fišerova testa, $p$ - Level of significance/ razina značajnosti

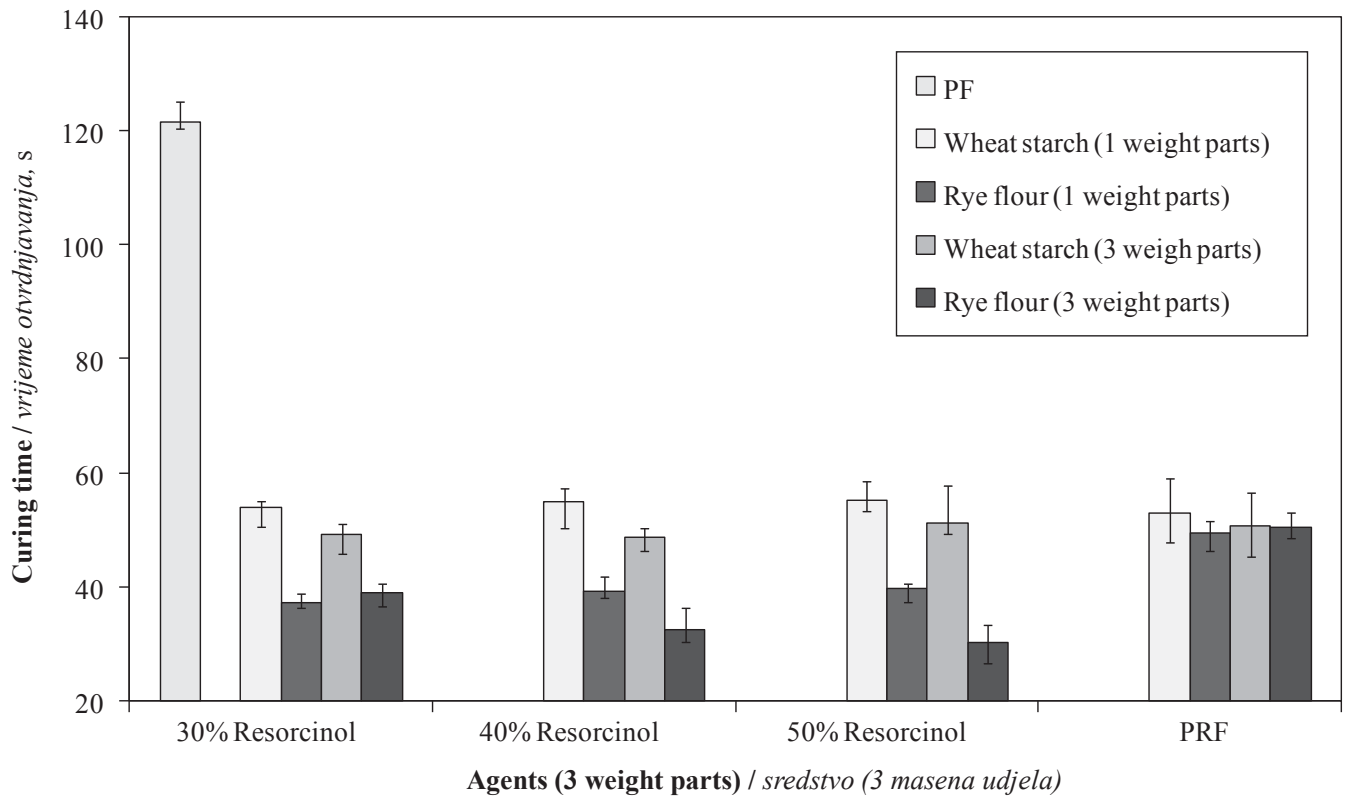

Figure 5 Curing times of adhesive compositions with different ratio of components Slika 5. Vrijeme otvrdnjavanja smjesa za lijepljenje pri različitim omjerima komponenata 


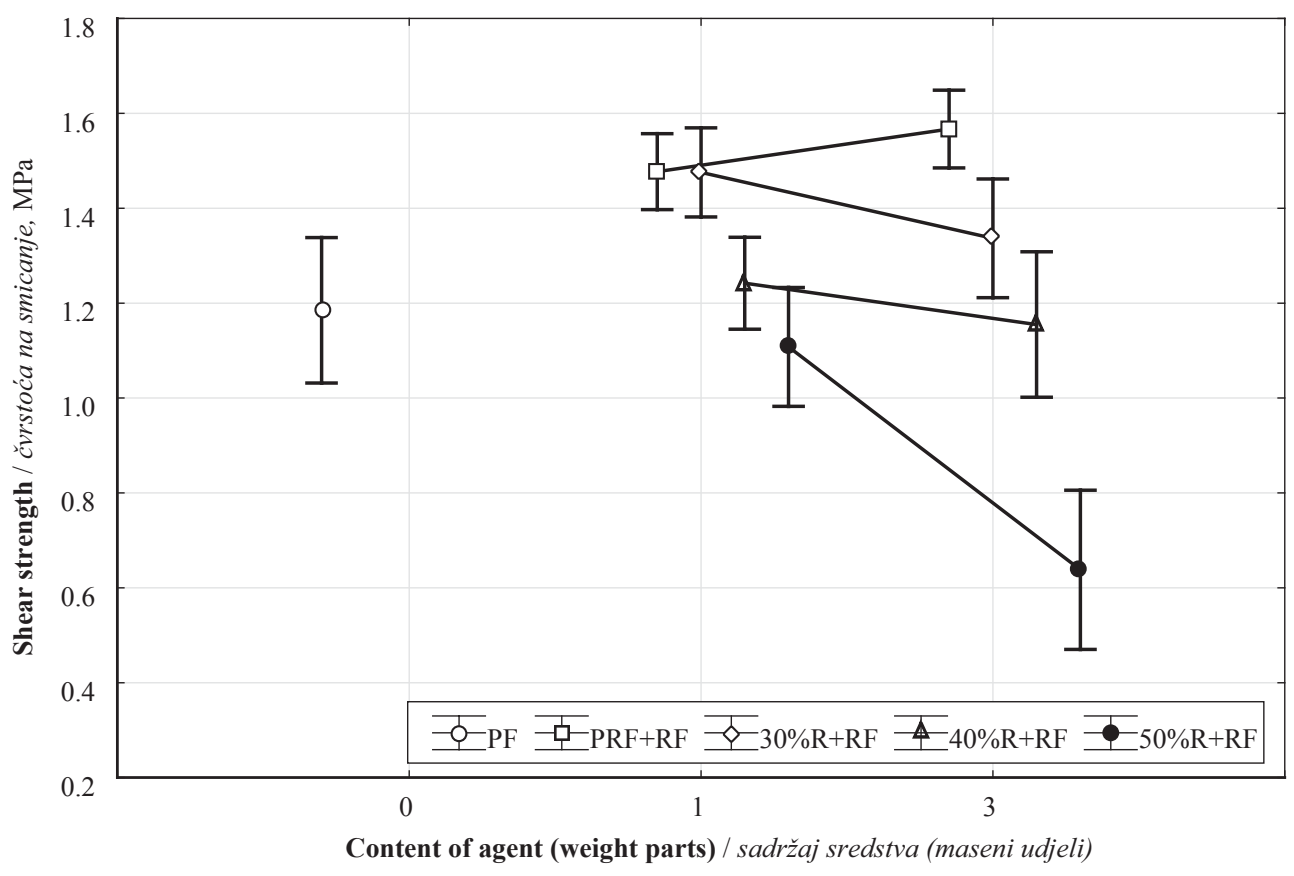

(a)

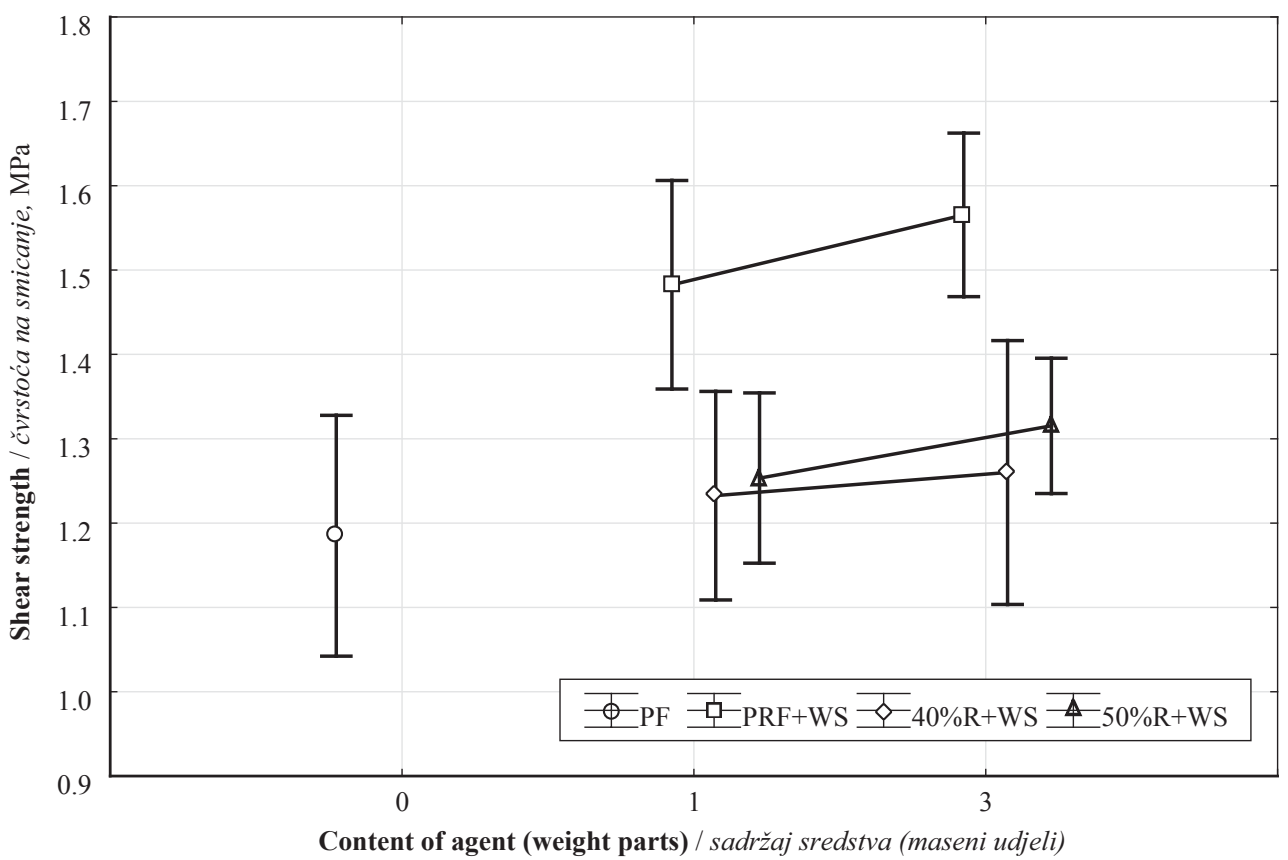

(b)

Figure 6 Shear strength of plywood panels made using a mixture of modifying agents

Slika 6. Čvrstoća na smicanje furnirskih ploča proizvedenih primjenom smjese sredstava za modificiranje ljepila

Increasing concentrations of resorcinol solution in a mixture with rye flour for any mass between ratios $1: 3$ or $3: 3$ lead to the decrease in shear strength of plywood because the dynamic viscosity of adhesive composition is significantly increased. In this case, worse glue wetting of the surface of veneer and thickening of the glue layer is observed. All of that leads to the reduction in shear strength. Similar behaviour of the dependence of shear strength of plywood is observed in the case of combining the resorcinol solutions with wheat starch by the ratio 1:3 (Figure 6a) or 3:3 (Figure $6 \mathrm{~b})$. Reactivity of resorcinol modified adhesives increases with increasing of resorcinol concentration in the solution. This leads to the rapid decrease of free reactive methylol groups, and reduction the adhesion strength of adhesive joint.

For adhesive compositions modified with PRF, regardless of its content in the mixture, the higher values of shear strength of plywood are provided in both cases in combination with rye flour and wheat starch.

\section{CONCLUSIONS \\ 4. ZAKLJUČAK}

Modified PF resin with selected modifying agents allows using veneer with moisture content of $15 \%$ for 
the manufacture of plywood in the laboratory scale, if their properties meet the standard requirements. Modifications of phenol-formaldehyde resin, in the way presented in this study, are possible with the use of wheat starch, rye flour, phenol-resorcinol-formaldehyde resin and $30 \%, 40 \%, 50 \%$ concentrations of resorcinol. The results of tests of shear strength properties of plywood show that mainly PRF glue compositions are most appropriate for the gluing of veneer with higher moisture content. The improvement of technical parameters of adhesive compositions and glued products strongly depend on the composition of glue mixture, functionality of modifiers and the way of modification. With the aim to decrease the over penetration of glues through the veneer during hot pressing, organic extenders were applied in gluing mixtures. ANOVA analysis has shown that type, mixture and content of modifying agents affect significantly the mechanical performance of plywood panels. The positive results from the laboratory experiments gave the base to plan experiments in industrial conditions, and however the application of some of them is limited due to their higher viscosity, mainly from the view of glue spread control. These glues have the solid content higher in comparison with reference PF resin.

\section{Acknowledgments - Zahvala}

This work was supported by Slovak Grant Agency VEGA under the contract No. 1/0581/12.

\section{REFERENCES}

\section{LITERATURA}

1. Besinova, O.; Katuscak, S.; Hespodarik, A.; Tokarova, L.; Lipka, R., 1997: Advantages and benefits of gluing of veneers with high moisture content for plywood producers. Adhesives in Woodworking Industry. Proceedings of XIII Symposium, Slovakia, pp.194-204.

2. Clark, R. J.; Karchesy, J. J.; Krahmer, R. L., 1988: Investigation of a new resin as an exterior adhesive to bond high moisture content veneers and glulam. Forest Products Journal, 38 (7/8): 23-28.

3. Clarke, M. E.; Steiner, P. R.; Anderson, A. W., 1990: Phenol-formaldehyde adhesive for bonding wood pieces of high moisture content and composite board and veneers bonded with such adhesive. U.S. Patent No. 4,897,314. U.S. Patent Off., Washington, D.C., 10p.

4. Elbez, G., 1997: Possibility of gluing of veneers with high moisture content. Adhesives in Woodworking Industry. Proceedings of XIII Symposium, Slovakia, pp. 101-110.

5. Hass, P.; Wittel, F. K.; Mendoza, M.; Herrmann, H. J.; Niemz, P., 2012: Adhesive penetration in beech wood: experiments. Wood Science and Technology, 46: 243256. http://dx.doi.org/10.1007/s00226-011-0410-6.
6. Jost, M.; Šernek, M., 2009: Shear strength development of the phenol-formaldehyde adhesive bond during cure. Wood Science and Technology, 43: 153-166. http://dx.doi.org/10.1007/s00226-008-0217-2.

7. Kamke, F. A.; Lee, J. N., 2007: Adhesive penetration of wood - a review. Wood Fiber Science, 39 (2): 205-220.

8. Mendoza, M.; Hass, P.; Wittel, F. K.; Niemz, P.; Herrmann, H. J., 2012: Adhesive penetration of hardwood: a generic penetration model. Wood Science and Technology, 46: 529-549.

http://dx.doi.org/10.1007/s00226-011-0422-2.

9. Pizzi, A., 2006: Recent developments in eco-efficient biobased adhesives for wood bonding: opportunities and issues. Journal of Adhesion Science Technology, 20 (8): 829-846.http://dx.doi.org/10.1163/156856106777638635.

10. Sellers, T. Jr.; Miller, G. D.; Nieh, W. L. S., 1990: Evaluation of three fillers in PF adhesives used to bond intermediate moisture content plywood: glueline durability and knife wear. Forest Products Journal, 40 (10): 23-28.

11. Skeist, I., 1977: Handbook of Adhesives, 2nd ed. New York: Van Nostrand Rheinhold Co, p. 921.

12. Steiner, P. R.; Troughton, G. E.; Andersen, A. W., 1993: Aqueous phenolic dispersions for bonding higher moisture content veneers. Forest Products Journal, 43 (10): 29-34.

13. Urbanik, E.; Jabloński, M.; Jóźwiak, M., 1997: Gluing high moisture content veneer with adhesives based on PRF and PF. In: Adhesives in woodworking industry. Proceedings of XIII Symposium, Slovakia, pp. 225-232.

14. Varivodina, I.; Kosičenko, N. E.; Varivodin, V. A.; Sedliačik, J., 2010: Interconnections among the rate of growth, porosity and wood water absorption. Wood Research, 55 (1): 59-65.

15. Vijayendran, B.; Clay, J., 2000: Some recent studies on soy protein-based wood adhesives. In: Wood Adhesives 2000, Extended Abstracts. Nevada, USA, Forest Products Society, pp. 4-5.

16. Waage, S. K.; Gardner, D. J.; Elder, T. J., 1991: The effects of fillers and extenders on the cure properties of phenol-formaldehyde resin as determined by the application of thermal techniques. Journal of Applied Polymer Science, 42: 273-278. http://dx.doi.org/10.1002/app.1991.070420131.

17. Wolcott, M. P.; Kamke, F. A.; Dillard, D. A., 1994: Fundamental aspects of wood deformation pertaining to manufacture of wood-based composites. Wood Fiber Science, 26 (4): 496-511.

\section{Corresponding address:}

Prof. Ing. PAVLO BEKHTA, Dr. Sc.

Department of Wood-Based Composites

National University of Forestry \& Wood Technology of Ukraine

Gen. Chuprynky 103

79057 Lviv, UKRAINE

e-mail: bekhta@ukr.net 